\title{
Research on Regional Differences of Peer-to-peer Lending in China
}

\author{
Yuhang Chen \\ School of Economics and Management \\ Nanjing University of Science and Technology \\ Nanjing, China
}

\author{
Yongjian Zong \\ School of Economics and Management \\ Nanjing University of Science and Technology \\ Nanjing, China
}

\begin{abstract}
This article studies regional differences of peerto-peer lending in China. We construct a novel index, called peer-to-peer lending development index, to measure the development level of peer-to-peer lending in different provinces. Using quarterly panel data from January 2014 to March 2016 in 28 Chinese provinces, we describe regional differences of peer-to-peer lending development level and identify the determinants of peer-to-peer lending development across regions. Based on our empirical findings, we provide policy recommendations for the development of peer-to-peer lending in China.
\end{abstract}

Keywords—peer-to-peer lending; regional difference; level of resident wealth; financing needs; level of resident consumption

\section{INTRODUCTION}

The 21 st century is the era of Internet. Because of it is convenience, Internet finance has developed rapidly in China after 2013. As an important type of Internet financial service, peer-to-peer lending has developed aggressively in China since then. The development level of peer-to-peer lending varies in different regions in China. While scholars have examined the status, prospects, and transaction success rate of peer-to-peer lending, there are few studies on the regional differences of peer-to-peer lending in China. This paper aims to analyze regional disparities of peer-to-peer lending in China. We construct a novel index, called peer-to-peer lending development index, to measure the development level of peer-to-peer lending in different provinces. Using quarterly panel data from January 2014 to March 2016 in 28 Chinese provinces, we describe regional differences of peerto-peer lending development level. We also carefully select explanatory variables to analyze the determinants of peer-topeer lending development in different regions. Our empirical results provide an in-depth understanding of the development of peer-to-peer lending in various regions in China. We conclude by providing some policy suggestions for stabilized and balanced develop ment of peer-to-peer lending in China.

\section{VARIABLES AND MODEL}

\section{A. Theoretical Basis}

Peer-to peer lending is an important type of Internet financial service. When studying the determinants of peer-topeer lending development, we use the methods that are commonly adopted in the research of Internet finance development. When considering regional factors, we obtain data from 28 provinces in China and divide them into 4 regions.

East: Beijing, Shanghai, Guangdong, Jiangsu, Zhejiang, Fujian, Tianjin, Hebei, Shandong, Hainan (10)

Middle: Hubei, Hunan, Shanxi, Henan, Anhui, Jiangxi (6)

West: Chongqing, Sichuan, Ningxia, Inner Mongolia, Xinjiang, Guangxi, Yunnan, Guizhou, Gansu, Shaanxi(10)

Northeast: Jilin, Heilongjiang (2)

\section{B. Variable Selection}

Given the limitation of data availability, we select the wealth level of residents, the consumption level of residents, and the financing demand of individuals and small and micro enterprises as explanatory variables. The adjusted Internet financial development index is the explained variable. We also use quarterly GDP as control variable in our regression. We obtain all raw data from the iFinD database.

1) Explained variable: The Internet Financial Development Index is compiled by the Research Group of the Internet Finance Research Center of Peking University that reflects domestic Internet finance development level. The comprehensive index is weighted by the development index of Internet investment, the development index of Internet money fund, the development index of Internet payment, and the development index of Internet insurance. Since peer-to-peer lending is not related to Internet payment and Internet insurance, we only select the development index of Internet investment and the Internet Monetary Fund. We adjust the Internet financial development index according to the weights of $70 \%$ and $30 \%$ to obtain a new development index. We call the new index the peer-to-peer lending development index.

2) Explanatory variable: Since the data of the explained variables are only updated to March 2016, we select quarterly data from January 2014 to March 2016.The following is a list of explanatory variables and their definitions. 
Wealth level of residents (deposit): the deposit balance of local and foreign currency of financial institutions in each province.

Consumption level of residents (consumption): total retail sales of consumer goods in each province.

Financing demand of individuals, small and micro enterprises (loan): the outstanding local and foreign currency loan balances of financial institutions in each province.

Gross Domestic Product (gdp): GDP of each province.

Population: the total population of each province.

\section{Modeling}

After collecting data of explanatory variables and explained variables, we construct panel data based on province and quarter. In order to eliminate multicollinearity, reduce the heteroskedasticity, and show the elasticity between the variables clearly, we estimate the log-linear regression model.

$\operatorname{lnindex_{i,t}}=\alpha_{i_{\mu} t}+\beta_{1 i_{\mu}, t} \ln d e p o s i t_{i_{\mu} t}+\beta_{2 i_{\omega} t} \ln l o a n_{i_{\mu} t}+$

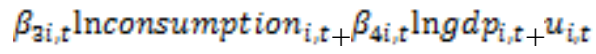

where i represents different provincest represents different quarters; ${ }^{u_{i}, t}$ is the random fluctuations in the model and $\alpha_{i, t}$ is a constant.

\section{EMPIRICAL ANALYSIS OF PANEL DATA}

\section{A. Unit Root Test and Model Selection}

To determine whether there is stationary sequence between explanatory variable and the explained variable, we carry out unit root test of peer-to-peer lending development index (index), the balance of foreign currency deposits of financial institutions per capita (deposit), the balance of foreign currency loans of financial institutions per capita (loan), retail sales of consumer goods per capita (consumption) and GNPP (gdp).

After completing unit root test in software Eviews, we find that the original sequence of the explanatory variables and explained variable is not stable (i.e. there is a unit root). However, the first-order difference sequence does not have a unit root and thus the sequence is stable. "Table I" shows the results of the unit root test.

TABLE I. Unit Root Test Results For Overall PANEL Data

\begin{tabular}{cccc}
\hline Variable & LLC & IPS & $\begin{array}{c}\text { ADF - Fisher } \\
\text { Chi-square }\end{array}$ \\
\hline index & $-14.8789 * * *$ & $-2.63307 * * *$ & $89.436 * * *$ \\
deposit & $-15.5942 * * *$ & $-5.60121 * * *$ & $143.032 * * *$ \\
loan & $-19.5939 * * *$ & $-7.94284 * * *$ & $162.392 * * *$ \\
consumption & $-22.1114 * * *$ & $-8.60177 * * *$ & $190.633 * * *$ \\
gdp & $-18.3316 * * *$ & $-9.61506 * * *$ & $211.632 * * *$ \\
\hline
\end{tabular}

a. Note: ***,and $* * *$ indicate significant tests at significant levels of $10 \%, 5 \%$ and $1 \%$ respectively.

To select random effect model and fixed effect model, we perform the Hausman Test on the panel data. As shown in "Table II", the Prob value is less than 0.05. Therefore, we reject the null hypothesis, and select the fixed effect model is selected. "Table II" shows the Hausman test results.

TABLE II. HAUSMAN TEST RESUlTS

\begin{tabular}{cccc}
\hline Variable & Chi-Sq. Statistic & Chi-Sq. d.f. & Prob. \\
\hline $\begin{array}{c}\text { Cross-section } \\
\text { random }\end{array}$ & 748.6892 & 4 & 0 \\
\hline
\end{tabular}

After selecting the fixed effect model, we consider the selection of variable intercept model and variable coefficient model under fixed effects. First, we run regression for the fixed intercept variable intercept model, as shown in "Table II".

TABLE III. REGRESSION RESULTS OF VARIABLE INTERCEPT MODEL UNDER FIXED EFFECTS

\begin{tabular}{ccc}
\hline Variable & $\begin{array}{c}\text { regression } \\
\text { coefficient }\end{array}$ & t-value \\
\hline deposit & $0.49 *$ & 1.67 \\
loan & $3.47 * * *$ & 11.29 \\
consumption & $0.62 * * *$ & 4.04 \\
gdp & -0.04 & -0.64 \\
\hline & & \\
a. $\quad$ Note: ***,and $* * *$ indicate significant tests at significant levels of $10 \%, 5 \%$ and $1 \%$ \\
respectively.
\end{tabular}

From the fixed-effect variable-intercept model regression results, we can see that the balance of foreign currency deposit of financial institutions per capita, the balance of foreign currency loans of financial institutions per capita, and retail sales of consumer goods per capita all have significant and positive effects on the peer-to-peer lending development index. According to the regression results, the balance of foreign currency loans of financial institutions per capita has the largest effect.

Through the fixed effect variable intercept model, we obtain the overall national regression estimation results. However, it is unclear how the results differ in different provinces. To select the variable intercept model and the variable coefficient model, we run regression for the variable coefficient model with fixed effects, as shown in "Table III": 
TABLE IV. REGRESSION RESULTS OF VARIABLE COEFFICIENT MODELS WITH FIXED EFFECTS

\begin{tabular}{|c|c|c|c|c|}
\hline & deposit & loan & consumption & gdp \\
\hline Beijing & $1.72 *$ & 0.55 & 0.96 & 0.19 \\
\hline Shanghai & 0.26 & -0.13 & 1.35 & -0.12 \\
\hline Guangdong & $1.75 *$ & 0.03 & 0.91 & -0.32 \\
\hline Jiangsu & 0.40 & 0.93 & 0.79 & 1.09 \\
\hline Zhejiang & -0.82 & $2.41 * *$ & 0.09 & 0.45 \\
\hline Fujian & 0.04 & 1.45 & 0.13 & -0.56 \\
\hline Tianjin & -1.42 & $3.05 * * *$ & -0.95 & 0.82 \\
\hline Hebei & -0.29 & 0.84 & 0.01 & -0.35 \\
\hline Shandong & -1.30 & 2. $10 * *$ & -0.67 & 0.37 \\
\hline Hainan & $-1.98 * *$ & 3. $10 * * *$ & 0.80 & 0.51 \\
\hline Hubei & 1.41 & -0.67 & 1.62 & 0.89 \\
\hline Hunan & -1.20 & $1.67 *$ & 0.86 & -1.14 \\
\hline Shanxi & $-2.40 * *$ & 3. $81 * * *$ & -1.44 & 0.57 \\
\hline Henan & -1.06 & $1.74 *$ & -0.29 & -1.06 \\
\hline Anhui & -0.89 & 1.15 & 0.28 & -0.62 \\
\hline Jiangxi & $-1.70 *$ & 2. $67 * * *$ & -0.51 & -0.73 \\
\hline Chongqing & -1.59 & 3. $50 * * *$ & 1.10 & -0.70 \\
\hline Sichuan & $-1.96 *$ & 2. $73 * * *$ & 0.25 & -1.16 \\
\hline $\begin{array}{l}\text { Ningxia } \\
\text { Inner }\end{array}$ & $-1.96 *$ & 3. $40 * * *$ & -0.28 & -0.36 \\
\hline Mongoria & $-2.55 * *$ & 3. $37 * * * *$ & -0.16 & -0.41 \\
\hline Xinjiang & 0.06 & 1.64 & 0.72 & -1.25 \\
\hline Guangxi & -1.39 & $2.60 * *$ & -0.22 & 0.11 \\
\hline Yunnan & -1.60 & $2.57 * *$ & 0.11 & 0.18 \\
\hline Guizhou & $-1.90 *$ & 2. $95 * * * *$ & 0.33 & -0.33 \\
\hline Gansu & -0.93 & 1.35 & 0.86 & -0.74 \\
\hline Shaanxi & $-1.84 *$ & 3. $08 * * * *$ & 0.56 & -0.83 \\
\hline Heilong jiang & -1.05 & 1.62 & 0.11 & -0.04 \\
\hline Jilin & $-1.83 *$ & $2.59 * *$ & -0.05 & 0.02 \\
\hline
\end{tabular}

a. Note: *,**and $* * *$ indicate significant tests at significant levels of $10 \%, 5 \%$ and $1 \%$

According to the regression results in "Table IV", the balance of foreign currency loans of financial institutions per capita has significant effects in most provinces, and the balance of foreign currency deposit of financial institutions per capita has significant effects in some provinces. Considering $R^{2}$ and the $\mathrm{F}$ statistic, we select variable intercept model with fixed effect.

After selecting the model, we perform unit root test of residual for the variable intercept model with fixed effect to make sure that there is a long-term stable relationship between the explained variable and the explanatory variables. The test results are shown in "Table V" below:

TABLE V. UNIT ROOT TEST RESULTS OF RESIDUAL FOR VARIABLE INTERCEPT MODEL WITH FIXED EFFECT

\begin{tabular}{cccc}
\hline Variable & LLC & IPS & ADF - Fisher Chi-square \\
\hline t-value & $-10.48 * * *$ & $-3.71 * * *$ & $113.45 * * *$ \\
\hline a. $\quad$ Note: $* * *$, and $* * *$ indicate significant tests at significant levels of $10 \%, 5 \%$ and $1 \%$ \\
respectively.
\end{tabular}

From the results in "Table V", the LLC, IPS and ADF test indicators all reject the null hypothesis. This implies that the residual sequence is stable and there is a cointegration relationship between explained variable and explanatory variables.
In the following, we examine the influence of explanatory variables on the explained variable from the lateral perspective. In the lateral analysis, we use the variable coefficient model with fixed effect.

\section{B. Regression Analysis of Overall Data}

1) Deposit-wealth level of residents: The following regression results show the impact of resident wealth on peer-to-peer lending development index in various provinces.

\begin{tabular}{|c|c|c|c|c|c|}
\hline \multicolumn{6}{|c|}{$\begin{array}{c}\text { TABLE VI. REGRESSION RESULTS UNDER VARIABLE COEFFICIENT } \\
\text { MODEL WITH FIXED EFFECT-THE BALANCE OF FOREIGN CURRENCY } \\
\text { DEPOSIT OF FINANCIAL INSTITUTIONS PER CAPITA }\end{array}$} \\
\hline & & regression & & & regression \\
\hline & & coefficient & & & coefficient \\
\hline \multirow{10}{*}{ East } & Beijing & $2.34 * * *$ & \multirow{10}{*}{ West } & Chongqing & $4.62 * * *$ \\
\hline & Shanghai & 0.35 & & Sichuan & $3.52 *$ \\
\hline & Guangdong & $2.47 * * *$ & & Ningxia & $3.59 * *$ \\
\hline & Jiangsu & $2.92 * *$ & & Inner Mongoria & $5.19 * * *$ \\
\hline & Zhejiang & $5.02 * * *$ & & Xinjiang & $4.76 * * *$ \\
\hline & Fujian & $4.49 * * *$ & & Guangxi & $4.03 * * *$ \\
\hline & Tianjin & $5.16 * * *$ & & Yunnan & $5.21 * * *$ \\
\hline & Hebei & $5.48 * * *$ & & Guizhou & 1.50 \\
\hline & Shandong & $4.36 * * *$ & & Gansu & 1.66 \\
\hline & Hainan & $2.69 *$ & & Shaanxi & $3.63 * *$ \\
\hline \multirow{6}{*}{ Middle } & Hubei & $3.04 * *$ & \multirow{6}{*}{ Northeast } & Heilongjiang & $7.44 * * *$ \\
\hline & Hunan & $3.02 * * *$ & & Jilin & $4.97 * * *$ \\
\hline & Shanxi & $9.58 * * *$ & & & \\
\hline & Henan & $3.50 * * *$ & & & \\
\hline & Anhui & 1.30 & & & \\
\hline & Jiangxi & $4.46 * * *$ & & & \\
\hline
\end{tabular}

As shown in "Table VI", the balance of foreign currency deposit of financial institutions per capita has significant and positive effect on peer-to-peer lending development index in most provinces except in Shanghai, Anhui, Guizhou and Gansu. The coefficients in Shanxi and Heilongjiang are larger than those in other provinces, indicating that they have a stronger influence on the peer-to-peer lending development index.

2) Loan-financing demand of individuals, small and micro enterprises: The following regression results show the impact of financing demand of individuals and small and micro enterprises on peer-to-peer lending development index in various provinces. 
TABLE VII. REGRESSION RESULTS UNDER VARIABLE COEFFICIENT MODEL WITH FIXED EFFECT-THE BALANCE OF FOREIGN CURRENCY LOAN OF FINANCIAL INSTITUTIONS PER CAPITA

\begin{tabular}{|c|c|c|c|c|c|}
\hline & & $\begin{array}{l}\text { regression } \\
\text { coefficient }\end{array}$ & & & $\begin{array}{l}\text { regression } \\
\text { coefficient }\end{array}$ \\
\hline & Beijing & $7.14 * * *$ & & Chongqing & $5.66 * * *$ \\
\hline & Shanghai & $5.50 * * *$ & & Sichuan & $5.63 * * *$ \\
\hline & Guangdong & $5.26 * * *$ & & Ningxia & $5.67 * * *$ \\
\hline & Jiangsu & $5.64 * * *$ & & Inner Mongoria & 4. $52 * * *$ \\
\hline Foct & Zhejiang & $8.43 * * *$ & West & Xinjiang & $5.00 * * *$ \\
\hline East & Fujian & $5.52 * * *$ & west & Guangxi & 4. $82 * * *$ \\
\hline & Tianjin & $7.69 * * *$ & & Yunnan & 4. $22 * * *$ \\
\hline & Hebei & 4. $72 * * *$ & & Guizhou & $2.98 * * *$ \\
\hline & Shandong & $6.96 * * *$ & & Gansu & 2. $86 * * *$ \\
\hline & Hainan & $3.37 * * *$ & & Shaanxi & 4. $65 * * *$ \\
\hline & Hubei & 4. $35 * * *$ & $\mathrm{~N}$ & Heilongjiang & 4. $10 * * *$ \\
\hline & Hunan & 4. $22 * * *$ & Northeast & Jilin & 4. $10 * * *$ \\
\hline & Shanxi & 7. $15 * * *$ & & & \\
\hline Miad & Henan & $4.54 * * *$ & & & \\
\hline & Anhui & $4.99 * * *$ & & & \\
\hline & Jiangxi & $3.82 * * *$ & & & \\
\hline
\end{tabular}

a. Note: *,**,and *** indicate significant tests at significant levels of $10 \%, 5 \%$ and $1 \%$ respectively.

From the results above, we can see that the balance of foreign currency loan of financial institutions per capita has a significant impact on the peer-to-peer lending development index in all provinces. The coefficient in the eastern region is generally greater than that in the central, western and northeast regions.

3) Consumption - consumption level of residents: The "Table VIII" shows the impact of resident consumption on peer-to-peer lending development index in various provinces.

TABLE VIII. REGRESSION RESUlTS UNDER VARIABLE COEFFICIENT MODEL WITH FIXED EFFECT-RETAIL SALES OF CONSUMER GOODS PER CAPITA

\begin{tabular}{|c|c|c|c|c|c|}
\hline \multicolumn{5}{|c|}{$\begin{aligned} \text { regression } \\
\text { coefficient } \\
\end{aligned}$} & $\begin{array}{l}\text { regression } \\
\text { coefficient }\end{array}$ \\
\hline \multirow{10}{*}{ East } & Beijing & 1.49 & \multirow{10}{*}{ West } & Chongqing & 0.42 \\
\hline & Shanghai & $3.89 * *$ & & Sichuan & 1.60 \\
\hline & Guangdong & 1.88 & & Ningxia & $1.92 * *$ \\
\hline & Jiangsu & $2.29 *$ & & Inner Mongoria & 0.67 \\
\hline & Zhejiang & 0.74 & & Xinjiang & 0.52 \\
\hline & Fujian & 0.83 & & Guangx i & 1.05 \\
\hline & Tianjin & 2.13 & & Yunnan & 0.68 \\
\hline & Hebei & 0.83 & & Guizhou & 1.11 \\
\hline & Shandong & 2. $13 * * *$ & & Gansu & 2.31 \\
\hline & Hainan & 1.40 & & Shaanxi & 1.33 \\
\hline \multirow{6}{*}{ Middle } & Hubei & $1.90 * *$ & \multirow{6}{*}{ Northeast } & Heilong jiang & $1.21 * *$ \\
\hline & Hunan & 1.02 & & Jilin & $1.50 *$ \\
\hline & Shanxi & 3. $39 * * *$ & & & \\
\hline & Henan & $1.77 *$ & & & \\
\hline & Anhui & 2. $72 * *$ & & & \\
\hline & Jiangxi & 0.64 & & & \\
\hline
\end{tabular}

a. Note: ***,and *** indicate significant tests at significant levels of $10 \%, 5 \%$ and $1 \%$ respectively.
Retail sales of consumer goods per capita has a significant and positive impact on the peer-to-peer lending development index in Shanghai, Jiangsu, Shandong, Hubei, Shanxi, Anhui, Ningxia and Heilongjiang. In terms of the degree of influence, resident consumption has the largest impact on the peer-to-peer lending development index in Shanghai.

The data in the above three tables show that Shanxi Province has a significant impact on the peer-to-peer lending development index in terms of the balance of foreign currency deposit of financial institutions per capita, the balance of foreign currency loan of financial institutions per capita and retail sales of consumer goods per capita. The impact and significance of the western region are the weakest. The provinces with significant impact in the central region have a large proportion, but except Shanxi Province, the coefficient is not large. There are certain differences in the coefficient between the various provinces in the eastern region, for different explanatory variables, different provinces have different degrees of influence.

\section{Regression Analysis of Regional Data}

We perform unit root tests on the variables in four regions respectively. The original sequence is not smooth, so we calculate the first-order difference. The results are shown in "Table IX".

TABLE IX. Unit Root TeSt RESUlts For REgIONAL PANEL DATA

\begin{tabular}{|c|c|c|c|}
\hline & Variable & LLC & $\begin{array}{c}\text { ADF - Fisher } \\
\text { Chi-square }\end{array}$ \\
\hline \multirow{5}{*}{ East } & index & 4. $63 * * *$ & $6.52 * *$ \\
\hline & deposit & 5. $03 * * *$ & $6.85 * *$ \\
\hline & loan & $-2.23 * *$ & 4. $96 *$ \\
\hline & con & $-2.09 * *$ & $4.62 *$ \\
\hline & $\operatorname{gdp}$ & 4. $26 * * *$ & $9.67 * * *$ \\
\hline \multirow{5}{*}{ Middle } & index & $3.86 * * *$ & $5.17 *$ \\
\hline & deposit & $-2.01 * *$ & $5.55 *$ \\
\hline & loan & 4. $32 * * *$ & $-7.55 * *$ \\
\hline & con & $-2.28 * *$ & $4.79 *$ \\
\hline & gdp & 2. $74 * * *$ & $6.94 * *$ \\
\hline \multirow{5}{*}{ West } & index & $-1.99 * *$ & $5.32 *$ \\
\hline & deposit & 2. $46 * * *$ & $5.04 *$ \\
\hline & loan & 2. $49 * * *$ & 4. $79 *$ \\
\hline & con & $-2.14 * *$ & $5.17 *$ \\
\hline & gdp & $-2.05 * *$ & $5.32 *$ \\
\hline \multirow{5}{*}{ Northeast } & index & $-2.06 * *$ & 2.65 \\
\hline & deposit & 4. $54 * * *$ & $6.70 * *$ \\
\hline & loan & 9. $63 * * *$ & $12.33 * * *$ \\
\hline & con & 2. $55 * * *$ & 7. $61 * *$ \\
\hline & gdp & $-2.26 * *$ & $5.93 *$ \\
\hline
\end{tabular}

a. Note: ***, and $* * *$ indicate significant tests at significant levels of $10 \%, 5 \%$ and $1 \%$

According to the results in "Table IX", 28 provinces have different degrees of significance in LLC and ADF-Fisher indicators. Therefore, we reject the null hypothesis and the first-order differential of panel data in each region is stable. We choose variable-intercept model according to the value of $R^{2}$.The regression results are shown in "Table X". 
TABLE X. REgRession Results of Regional Panel Data

\begin{tabular}{ccccc}
\hline & East & Middle & West & Northeast \\
\hline deposit & $1.95 *$ & 2.56 & 2.81 & 3.41 \\
& $(1.97)$ & $(1.87)$ & $(1.59)$ & $(1.58)$ \\
loan & $4.69 * *$ & $4.01 * * *$ & $4.01 * *$ & $3.07 * *$ \\
& $(2.73)$ & $(3.65)$ & $(3.34)$ & $(2.75)$ \\
con & 0.93 & 0.66 & 0.48 & 0.19 \\
& $(1.22)$ & $(0.96)$ & $(0.90)$ & $(0.74)$ \\
gdp & 0.15 & -0.02 & -0.21 & 0.09 \\
& $(-0.47)$ & $(-0.06)$ & $(-1.86)$ & $(0.63)$ \\
\hline
\end{tabular}

a. Note: *,**, and $* * *$ indicate significant tests at significant levels of $10 \%, 5 \%$ and $1 \%$

The wealth level of residents (i.e. the balance of foreign currency deposit of financial institutions per capita) has a significant and positive impact on the peer-to-peer lending development index in the eastern region, and the coefficient is low. Financing demand of individuals and small and micro enterprises (i.e. the balance of foreign currency loans of financial institutions per capita) has a significant impact on the peer-to-peer lending development index in all four regions, and the coefficient of eastern region is largest. Consumption level of residents (i.e. retail sales of consumer goods per capita) does not have a significant impact on the peer-to-peer lending development index in any region. Only financing demand of individuals and small and micro enterprises have significant and positive effect on the peerto-peer lending development in all the regions.

Adequate balance of foreign currency deposit and loan of financial institutions reflect the financing demand of individuals and small and micro enterprises, and it is closely related to the functions of the peer-to-peer lending. Therefore, the result that financing demand of individuals and small and micro enterprises has a significant impact on the peer-to-peer lending development index is reasonable. Under a perfect financial environment, wealth level of residents should also have a significant and positive effect on the peer-to-peer lending development index. The regression results show such an effect relies on financial environment. In the eastern region, where the financial environment is healthy, resident wealth level has a significant and positive effect on the peerto-peer lending development index. In regions where the financial environment is poor and the degree of penetration is low, there is no such effect.

To make sure that there is long-term stable relationship between explained variable and explanatory variables in each region, we perform the ADF test in the model residuals in the four regions. "Table XI" shows the ADF test results.

TABLE XI. UNIT Root TEST RESUlts For RESIDUAL SERIES OF REGIONAL PANEL DATA

\begin{tabular}{ccccc}
\hline & East & Middle & West & Northeast \\
\hline t-value & $-3.90 * *$ & $-3.52 *$ & $-2.56 *$ & $-2.26 *$ \\
\hline
\end{tabular}

a. Note: *,**,and $* * *$ indicate significant tests at significant levels of $10 \%, 5 \%$ and $1 \%$ respectively

From the results in the above "Table XI", we can see that the residual sequences in the four regions are stable at different levels. There is a cointegration relationship between the explained variable and the explanatory variables. Therefore, the relationship between the explained variables and explanatory variables in the four regions is long-term.

\section{CONCLUSION}

\section{A. Analysis Conclusion}

From the empirical results, there are indeed regional differences in the determinants of the development level of peer-to-peer lending.

Regressions using provincial data show that resident wealth level, the financing needs and resident consumption level all have significant and positive impact on the development of peer-to-peer lending. The effect of resident wealth level and resident consumption level on the development of peer-to-peer lending is low, while the financing needs of individuals and small and micro enterprises has a relatively larger impact on the development of peer-to-peer lending.

Regressions using regional data show that not all explanatory variables have significant impact on the explained variable. The consumption level of residents has no significant impact on peer-to-peer lending development index. The wealth level of residents only has a significant positive effect on the development of peer-to-peer lending in the eastern region where the relative economic development level is high. Financing demand has a significant impact in all the four regions, but there are differences in the coefficient.

\section{B. Policy Suggestion}

The unbalanced regional development of peer-to-peer lending still exists. The government needs to adjust and improvements to the most critical factors in the development of peer-to-peer lending, and reasonably coordinate the policy about the wealth level of residents, the financing needs of individuals and small and micro enterprises, and consumption level of residents. In the short term, policy guidance can be given to the impact factors which have largest impact on peer-to-peer lending development index. This may help balance peer-to-peer lending development index in different regions in the short term. At the same time, we must address the weaknesses of different regions, actively remedy the shortcomings, and tap the potential of their developmental relevance in the long term.

Economic Transformation. The level of economic development has affected the balance of local and foreign currency deposits and loans of financial institutions in various regions. It has also influenced the development of peer-to-peer lending in various regions in different degrees. Therefore, all regions should continue to maintain rational use of advantageous resources. For the middle, western, and northeast regions, they can seek new directions for development in the long term based on local conditions.

Regional financial policy. Differences in different regions need to consider the corresponding resource advantages and disadvantages, and formulate financial 
policies that belong to the region. Regions should maximize the peer-to-peer lending at the lowest cost to alleviate the current imbalance of China's domestic peer-to-peer lending development imbalance and narrow the development gap between regions and provinces.

Specifically, in developed provinces such as Beijing, Shanghai, Guangdong, Jiangsu, Zhejiang and Shandong, it is necessary to strengthen the risk supervision of the peer-topeer lending industry and strengthen the propaganda of peerto-peer lending for residents to maintain healthy and stable development.

For the central region, it is necessary to increase policy and economic support for Hubei and Shanxi, while ensuring that there is no leakage in supervision and risk in the process of rapid development. Hubei Province can make full use of its geographical advantages in transportation to attract highend talents in finance.

In the western region, Shaanxi, Chongqing and Sichuan are in the forefront of peer-to-peer lending development. While Ningxia's current absolute development level is low, it shows the largest potential in the west. Given the overall economic development level and location of the western region, the economic transformation should be their primary goal. The catch-up of peer-to-peer lending development in these provinces is a long-term process.

\section{REFERENCES}

[1] Xie Ping, Zou Chuanwei. Research on internet financial model [J]. Financial Research, 2012, (12): 11-22.

[2] Chen Zhiwu. How new is Internet finance?[J]. New Finance, 2014, (04): 9-13.

[3] Zhan Zhenghua, Wu Xun. Research on the Evaluation of Peer-to-peer Lending Platform Competitiveness in China[J]. Finance and Economics, 2017, (02): 92-96+74

[4] Cheng Junjun. Research on the Status and Problems of Peer-to-peer Lending Platform in China[J]. Brand, 2015, (05): 32.

[5] Ma Beibei. Research on Regional Differences of Peer-to-peer Lending in China.[D]. Zhejiang Gongshang University, 2016.

[6] Zhao Peipei. Analysis of Influencing Factors on Comprehensive Returns of Peer-to-peer Lending Industry[J]. Economic Forum, 2017, (03): 61-65.

[7] Zeng Zhi. Research Report on Peer-to-peer Lending Industry in China[D]. Southwestern University of Finance and Economics, 2014.

[8] Jiang Yuyao. Influencing factors and regional differences in the development of internet finance[D]. Nanjing University, 2016. 